\title{
Sport Scandal Investigations: An 'Independent' Solution or Part of the Problem?
}

\begin{abstract}
Joanna Wall Tweedie*
This study investigated the use and content of sports scandal investigation reports. Many such reports are self-described as "independent." This paper serves to elucidate some of the issues around "independence" and limitations of these investigations. The analysis is discussed in connection to the unique context of sport governance structures and policy, along with the related issues of autonomy, transparency, and accountability. A content analysis method was employed to analyze a purposive sample of post-scandal reports from the past decade pertaining to international professional sport. The results revealed the efforts to portray independence in the reports and identified potential threats to independence. The analysis and corresponding discussion provide recommendations for future report procedure, interpretation, evaluation, and legal policymaking.
\end{abstract}

Keywords: sport scandal, independent reports, governance, integrity

\section{Introduction and Background}

When sports scandal erupt, sports governance is called into question and an investigation is frequently turned to for answers. Many such investigations and reports are self-described as being "independent". The post-scandal "independent" investigation reports are often seen as the key first step to restoring public faith in the integrity of the sport concerned. These reports are devoured by the media and relied upon as the source for accurate information and rarely themselves called into question. However, it is essential to position these reports within broader issues of sport governance, legal policy, and integrity. The aim of this study was to evaluate post-scandal investigation reports in global sport.

The integrity of sport is vulnerable to scandal. For example, McLaren (2011) argued that the intrusion of performance enhancing drugs and gambling threatens the public image of sport and are "the greatest threats to the continued commercial success of professional sport" (p. 551). McLaren accused sport administrators of being unwilling to adequately attend to problems that threaten sports integrity:

\footnotetext{
* Joanna Wall Tweedie is a doctoral candidate in the sport management program at Florida State University; email: jtweedie@fsu.edu
} 
The problems languish in the background of sport and struggle to receive the attention and willingness of sports administrators to eradicate them. A culture of fame and admiration, combined with profits and wealth, seems to matter above all else, particularly in professional sport. (McLaren, 2011, p. 551)

Post-scandal investigation reports arise in the context of sports corruption and concern the restoration of sports integrity. However, McLaren discussed The Mitchell Report (2007) and criticized the creation of the report as "a late reaction to a problem that MLB [Major League Baseball] was aware of before the independent report," and stressed that the investigation is "only a waypoint to solving the problem" (McLaren, 2011, p. 559). This present study addresses an overarching question as to whether these "independent" investigation reports should be considered part of a solution in the wake of sports scandal, or a symptom of prevailing sport governance problems. Specifically, the study is concerned with how "independence" is claimed and emphasized in these documents, and identified threats to claims of "independence."

The global sports community has faced no shortage of scandal in recent years. The sports of football, soccer, and track and field provide clear examples of sports scandal and subsequent investigation reports. Football's international governing body (Federation Internationale de Football Association, FIFA) has become synonymous with corruption since allegations of bribery began circling in 2010 following the allocation of the 2018 and 2022 World Cup hosting rights to Russia and Qatar, respectively (Independent, 2015). The FIFA story gained momentum and in 2015 both Swiss and United States law enforcement authorities arrested FIFA officials and launched investigations into fraud, racketeering, and money laundering (Independent, 2015). The Swiss officials' and the Federal Bureau of Investigation's (FBI) inquiries were preceded by an investigation commissioned by FIFA; the internal summary report had cleared Russia and Qatar from any wrongdoing in the World Cup bidding process. Michael Garcia, the U.S. attorney who had been responsible for the internal FIFA investigation, described the summary report released by FIFA as "erroneous representations of the facts and conclusions" of his still-sealed full report (Longman, 2014). The procedures continued in 2017 when FIFA concluded a 22-month internal investigation, and provided a 1,300-page report of its findings to Swiss and U.S. law enforcement authorities (Homewood, 2017). Additionally, the bidding process for the 2022 FIFA World Cup was "independently" overseen by the accounting and consulting firm Klynveld Peat Marwick Goerdeler (KPMG)_KPMG was also FIFA's external auditor, and the adviser and auditor for the Russia and Qatar organizing committees (Independent, 2015). Clearly, "independent" can have many different definitions.

Cycling has been tainted by doping scandal for decades. In March 2015, the Cycling Independent Reform Commission (CIRC) released its report following a 13-month investigation and suggested that doping remains widespread in the sport and also painted a negative picture of cycling's international governing body (Union Cycliste Internationale, UCI) as having allowed the culture of doping to prevail. For the sport of track and field, the scandal also has been doping related. In November 2015, a World Anti-Doping Agency (WADA) Independent 
Commission (IC) released its findings (WADA IC I) after an almost year-long investigation into allegations of systematic and sophisticated state-sponsored doping within Russia's athletics governing body (All-Russia Athletic Federation, ARAF). Revelations in this report (WADA IC I) ultimately resulted in the suspension of the ARAF from international competition. The international implications of the track and field saga became clear in January 2016, when the second IC report (WADA IC II) detailed the International Association of Athletics Federation's (IAAF) involvement and confirmed corruption at the highest level of the organization (WADA, 2016). In December 2016, the IAAF announced the formation of an Athletics Integrity Unity. In a press release, the IAAF described that the proposed Athletics Integrity Unit "will be a fiercely independent organization with responsibility for the management of all aspects of the anti-doping programme for international-level athletes and their athlete support personnel as well as for the management of all other integrity-related programmes operated in elite athletics" (IAAF, 2016). Evidently, no matter how large the scandal, the repair requires vociferous proclamations of "independence."

These examples depict the emphasis of "independence" in the proposed solutions when the integrity of sport is called into question because of doping, match fixing, bid rigging, financial improprieties, or any number of other sports scandals. This paper elucidates some of the issues around "independence" and limitations of these post-scandal investigations in the sports industry. A legal definition provides a useful lens for evaluating claims of "independence." "Independent" is defined in Black's Law Dictionary (2014) as: "not subject to the control or influence of another" (independent investigation) and "not dependent or contingent on something else" (an independent person). In the present study, a content analysis method was employed to analyze a purposive sample of post-scandal reports from the past decade pertaining to international professional sports. The content analysis depicts the efforts to portray independence in the reports, and criteria connected to independence. Consistent with the aforementioned definition, threats to independence were identified whereby the commissioning body may influence or control the outcome of the investigation. Additionally, additional criteria for evaluating these reports and recommendations for improved use and interpretation are provided. Results are discussed in relation to sport governance and legal policy, including future implications. Furthermore, the exploratory nature of this preliminary analysis informs suggestions for future empirical research.

\section{Literature Review}

The present study is positioned within the sport scandal and integrity literature. Sport scandal has been conceptualized as "either illegal or unethical, involve multiple parties over a sustained period of time, and whose impact affects the integrity of the sport with which they are associated" (Hughes \& Shank, 2005, p. 214). Sport scandals can originate with a single perpetrator or involve multiple perpetrators (Chien, Kelly, \& Weeks, 2016; Fink, Parker, Brett, \& Higgins, 2009). Furthermore, a sport scandal may be associated with a single incidence (e.g., Ray Rice assault case) or multiple occurrences (e.g., systematic doping). Professional sports' high profile and rising number of commercial activities results in these 
scandals attracting large-scale media attention and the prolific dissemination of negative information. The associated negative publicity and perceptions can impact connected stakeholders, including sporting governing bodies and sponsors (Chien, Kelly, \& Weeks, 2016; Wilson, Stavros, \& Westberg, 2008). Existent literature has focused upon fans' responses to sport scandal (Fink et al., 2009; Lee, Bang, \& Lee, 2013), implications in sponsorship (Chien, Kelly, \& Weeks, 2016; Wilson, Stavros, \& Westberg, 2008), and the media's framing of the scandal (Hughes \& Shank, 2005). There has been a lack of academic consideration of the actions aimed at restoring sport integrity, particularly the role of the post-scandal "independent" investigations.

McLaren (2011) argued that sporting integrity is under increasing threat, especially due to performance enhancing drugs and gambling, and suggested that sport administrators are "deliberately inept and unwilling" (p. 552) to prevent these problems. He stated, "the effect of inadequate pursuit of existing regulation and its lack of administration enforcement, when combined with ineffective adjudication, are leading to an erosion of sporting integrity" (McLaren, 2011, p. 552). McLaren provided some thought on "independent" investigations and suggested that these can be utilized to expose problems and provide recommendations; however, he concedes that these reports are expensive and are only a "waypoint." The current study was designed to extend the analysis of sport integrity, concentrating of the investigation report itself.

While professional sport can be considered a unique context, (non-sport) corporate scandals offer pertinent comparisons for the present study. At the turn of the 21st century, America was shaken by corporate scandals (e.g., Enron, WorldCom, Tyco, Xerox). Mismanagement, the failure of monitoring systems, and conflicts of interest played a central role in these scandals (Kuhn \& Ashcraft, 2003; Levitt \& Dwyer, 2002; Moore et al., 2006). Management scholars have analyzed the American business model and depicted pervasive conflicts of interest and the severe erosion of financial auditor independence (Moore et al, 2006). A full review of this literature is beyond the scope of this paper; however, an appreciation of the forces that shaped these corporate scandals provides guidance for the analysis of sport scandal. Specifically, the current study considered conflicts of interest and claims of "independence" within the investigations that followed the sport scandals.

\section{Method}

Content analysis is a systematic and replicable method for analyzing documentation (Kassarjian, 1977). Content analysis was identified as a research tool that would enable the level of exploration and reduction of qualitative data required (Creswell, 2007; Patton, 2002) and assist with identifying themes or patterns related to investigating "independence." Specifically, a directed content analysis was chosen as the most appropriate method; Hsieh and Shannon (2005) noted that a directed content analysis is used when existing research is incomplete or would benefit from further description. The goal of a directed approach to content analysis is to conceptually validate or extend a theory or theoretical framework (Hsieh \& Shannon, 2005) and this analysis was aimed at extending theory regarding "independence" and limitations of these post-scandal sport investigations. 


\section{Sample Selection}

A purposive sample of 18 sport scandal investigation reports pertaining to international governing bodies were utilized in this study. These reports were those only from the past decade (2007-2016) at the time this research project was launched. Sport scandals and independent investigations depict various issues pertinent to the global sport community, and this study aimed to offer a comparative analysis and a platform for further wider exploration. Additionally, the analysis provided opportunity to compare how these reports are utilized by different sport organizations.

A list of high-profile sport scandals over the past decade was compiled utilizing publicly available sources. Professional sport was determined as the sample parameter, ensuring a high level of media interest and allowing for discussions around any possible public relations function that these reports may provide. Scandals related to U.S. collegiate athletes were not utilized in the sample due to the amateur nature of the National Collegiate Athletic Association (NCAA) and the distinct context being unusual in the global sport community. The sample did not include equine or dog racing, nor games (e.g., bridge, chess, poker). Including a sample across sports, pertaining to individual or team, and over a decade time period, also allowed for any differences and trends to be observed. Furthermore, the reports analyzed in this present study were limited to those in published in the English language. It was not intended that the sample utilized would be an all-encompassing representation of sport independent investigation reports, but it is suggested that the range of reports provides a representative sample. Table 1 provides an overview of the 18 reports utilized in the sample to provide context and support interpretation and discussion.

\section{Coding and Analysis}

The coding criteria was compiled pertaining to two key areas, the content emphasizing purported independence and potential threats to actual independence. Kassarjian (1977) advised that the categories and criteria should be clearly defined by an explicit set of rules for content analysis as the rules affect objectivity and reliability. Clear categories were identified for coding the reports to ensure systematic, reproducible, and easily interpreted findings were obtained. These criteria suited the limited scope of the study and the goal to provide a platform for future discussions. The content analysis approach used for analysis makes it possible to draw inferences with analytical (not statistical) generalizability (Yin, 2003).

To enhance the validity of this study, each report was considered for any additional content depicting an emphasis on "independence" or that was suggestive of potential conflicts. This was essential to ensure relevant content would be represented and emergent themes considered in the findings. Therefore, both deductive and inductive analysis occurred. Inductive analysis provides for the identification or discovery of themes that emerge from the data (Patton, 2002). In allowing for this provision, the study aimed to address the importance of methodological appropriateness whereby the units of analysis would be context-responsive (Patton, 2002). 
Table 1. Sample

\begin{tabular}{|c|c|c|}
\hline $\begin{array}{l}\text { Investigation } \\
\text { Report } \\
\text { Reference } \\
\text { Name }\end{array}$ & Year & Brief Summary \\
\hline Mitchell Report & 2007 & $\begin{array}{l}\text { MLB steroid scandal. Investigation into the use of steroids and performance enhancing drugs in } \\
\text { Major League Baseball, provided history and recommendations for prevention programs. Report } \\
\text { named over } 80 \text { past and current players alleged to have used performance enhancing drugs. }\end{array}$ \\
\hline Gunn and Rees & 2008 & $\begin{array}{l}\text { Tennis gambling scandal. Investigation into threats to the integrity of professional tennis and } \\
\text { made recommendations to address them. Recommendations included the creation of a global } \\
\text { integrity unit. Concluded there is not institutionally or systematically corrupt. Investigated } 73 \\
\text { matches over the previous five years involving suspected betting patterns. Further examined } 45 \\
\text { of those matches and suggested specific concerns that would warrant further review. Gunn and } \\
\text { Rees had both worked on anti-corruption programs in other sports. Report commissioned by ITF, } \\
\text { ATP, WTA, and the four grand slam tournaments. }\end{array}$ \\
\hline Pedowitz Report & 2008 & $\begin{array}{l}\text { NBA referee gambling scandal. NBA commissioned investigation by former federal prosecutor, } \\
\text { Lawrence Pedowitz, following the gambling scandal whereby Tim Donaghy, NBA referee, was } \\
\text { betting on NBA games he officiated and providing confidential NBA information to bookies and } \\
\text { gamblers. Pedowitz concluded that no other NBA referee had engaged in illegal gambling. The } \\
\text { report included recommendations for improved anti-gambling policies for the NBA. }\end{array}$ \\
\hline $\begin{array}{l}\text { USADA Armstrong } \\
\text { Report }\end{array}$ & 2013 & $\begin{array}{l}\text { Lance Armstrong doping scandal. Report detailed the decision by United States Anti-Doping } \\
\text { Agency (USADA) for its imposed sanction of lifetime ineligibility and disqualification of } \\
\text { competitive results achieved during his career. }\end{array}$ \\
\hline Weiss Report & 2013 & $\begin{array}{l}\text { NBPA corruption scandal. Investigated allegations of nepotism and conflicts of interest in } \\
\text { NBPA. Investigators concluded that executive director Billy Hunter did not engage in criminal } \\
\text { acts involving embezzlement or theft of union funds. Yet the report states, "Mr. Hunter's actions } \\
\text { were inconsistent with his fiduciary obligations to put the interests of the union above his } \\
\text { personal interests." }\end{array}$ \\
\hline Wells I & 2014 & $\begin{array}{l}\text { Miami Dolphins bullying scandal. NFL commissioned Theodore Wells to investigate allegations } \\
\text { of bullying by the Miami Dolphins. Report found consistent patterns of harassment by players } \\
\text { Richie Incognito, John Jerry, and Mike Pouncey that had ultimately resulted in player Jonathon } \\
\text { Martin leaving the team. Players were suspended and new workplace conduct policies and } \\
\text { guidelines were recommended. }\end{array}$ \\
\hline Mueller Report & 2015 & $\begin{array}{l}\text { Ray Rice domestic violence scandal. NFL commissioned investigation into the NFL's handling of } \\
\text { Ray Rice's assault of his fiancé. The NFL had suspended Rice for two weeks and then indefinitely } \\
\text { once footage of the assault became public. Robert Mueller concluded the NFL had not received } \\
\text { the video of the incidence prior to its public release but the NFL should have done more to obtain } \\
\text { further information. }\end{array}$ \\
\hline Wells II & 2015 & $\begin{array}{l}\text { NFL “Deflategate" scandal. NFL commissioned Theodore Wells to investigate the New England } \\
\text { Patriots' use of partially deflated footballs in the AFC Championship Game. Concluded that } \\
\text { New England Patriots' personnel participated in violations of the rules and were involved in a } \\
\text { deliberate effort to circumvent the rules, and that quarterback Tom Brady was aware. Brady was } \\
\text { suspended for four games and the team fined \$1 million. }\end{array}$ \\
\hline CIRC Report & 2015 & $\begin{array}{l}\text { Cycling doping scandal. The report was after a 13-month investigation by the Cycling } \\
\text { Independent Reform Commission (CIRC) funded by the UCI. Report included history of doping } \\
\text { within the sport of cycling, details of current suspected doping methods, and recommendations } \\
\text { for the future. No new admissions of doping or proof that the UCI facilitated or covered up } \\
\text { doping. }\end{array}$ \\
\hline
\end{tabular}




\begin{tabular}{|c|c|c|}
\hline $\begin{array}{l}\text { CONCACAF } \\
\text { Integrity } \\
\text { Committee Report }\end{array}$ & 2013 & $\begin{array}{l}\text { CONCACAF's corruption scandal. Integrity committee was established by the Executive } \\
\text { Committee of CONCACAF. The investigation focused on Jack Warner (former CONCACAF } \\
\text { president) and Chuck Blazer (former CONCACAF general secretary). The report concluded that } \\
\text { Warner and Blazer committed an extensive list of fraud and misappropriation of funds. }\end{array}$ \\
\hline Pieth FIFA Report & 2011 & $\begin{array}{l}\text { FIFA Corruption scandal. Mark Pieth was commissioned by FIFA to analyze the existing } \\
\text { governance structure. The investigation scope was detailed as, "... not an investigation into } \\
\text { past behavior. The focus is exclusively on the institutional arrangements, the organizational } \\
\text { structures and procedures and their ability to deal with existing risks and challenges." Report } \\
\text { included recommendations for reform and resulted in formation of Independent Governance } \\
\text { Committee (IGC). }\end{array}$ \\
\hline $\begin{array}{l}\text { FIFA IGC: } \\
\text { Report I } \\
\text { Report II } \\
\text { Report III }\end{array}$ & $\begin{array}{l}2012 \\
2013 \\
2014\end{array}$ & $\begin{array}{l}\text { FIFA Corruption scandal. The Independent Governance Committee (IGC) included Mark Pieth. } \\
\text { These reports serve as progress reports from the IGC in relation to FIFA Governance Reform } \\
\text { Project. }\end{array}$ \\
\hline WADAICI & 2015 & $\begin{array}{l}\text { Russian athletics doping scandal. The WADA Independent Commission (IC), chaired by Dick } \\
\text { Pound, released its first report following an almost year-long investigation into allegations } \\
\text { of systematic and sophisticated state-sponsored doping within Russia's athletics governing } \\
\text { body (ARAF). Concluded doping program had benefitted Russian athletes from Olympic and } \\
\text { Paralympic sports over a time period of, at least, } 2011 \text { to August 2015. The first report ultimately } \\
\text { resulted in the suspension of the ARAF from international competition. }\end{array}$ \\
\hline WADA IC II & 2016 & $\begin{array}{l}\text { Russian athletics doping scandal. The second IC report details the International Association of } \\
\text { Athletics Federations (IAAF) involvement in state sponsored doping within ARAF and confirms } \\
\text { corruption at the highest level of the organization. }\end{array}$ \\
\hline McLaren IP & 2016 & $\begin{array}{l}\text { Sochi doping scandal. Richard McLaren was appointed by WADA as an independent person "IP" } \\
\text { to investigate allegations into state-run doping during the Sochi } 2014 \text { Winter Olympic Games. } \\
\text { Concluded that Moscow and Sochi laboratories worked for the protection of doped athletes and } \\
\text { this was overseen by the Ministry of Sport. McLaren was previously a member of WADA's IC, } \\
\text { which exposed widespread doping in Russian athletes. The report analyzed in the study was the } \\
\text { second and final IP report released by McLaren. }\end{array}$ \\
\hline Ruggie Report & 2016 & $\begin{array}{l}\text { FIFA's human rights abuse scandal. Following substantial accusations of human rights abuse, } \\
\text { FIFA commissioned Human Rights expert John Ruggie "to develop recommendations on what it } \\
\text { means for FIFA to embed respect for human rights across its global operations" (p. 4). The report } \\
\text { utilized the United Nations Guiding Principles on Business and Human Rights and then presented } \\
25 \text { detailed recommendations for action. }\end{array}$ \\
\hline
\end{tabular}

\section{Results and Discussion}

Table 2 summarizes the results of the content analysis.

\section{The Emphasis and the Explanation of 'Independence'}

The first group of variables used in the content analysis pertained to how "independence" was emphasized and justified in each report. Each report was assessed for the frequency of the use of the word "independent" and this provides quantification of the emphasis of "independence" in these documents. Six of the reports contained the word "independent" 50 or more times. Additionally, half (9) of the reports included "independent" in the title. The first WADA IC report (WADA IC I) included the word "independent" at the highest frequency, 83 
times. WADA IC I was a large report with 335 pages; however, it is nonetheless noteworthy that the acronym IC (Independent Commission) was used over 700 times in the document. Another variable used in the content analysis pertained to the amount of explanation provided to explain "independence" (section or statements). It was observed that four of the reports had sections devoted to an explanation of "independence," and the remainder of the reports included minimal qualification as to what constituted "independent." Additionally, each report was analyzed for how independence was claimed and emergent themes categories identified (refer to Table 2, final column). Most of the reports (15) claimed externality as the rationale for "independence"- these reports mention that the person(s) charged with the investigation is external to the subject of the inquiry.
There is a limitation in using word frequency as a metric, such that the word "independent" may have been used at times in the report in reference to something other than the report itself. However, it can be concluded that there is an emphasis on "independence" in dealing with sport scandal. The prolific inclusion of "independent" as a noun, and within acronym nouns (i.e., IC, CIRC, IP [Independent Person]) may depict a significant step in the attempts to portray independence. It is apparent that proclaimed "independence" was an important feature of these reports; however, there was little clarification in any of the reports about what actually constituted "independence."

A clear example of the deliberate emphasis on "independence" is in the McLaren IP Report whereby McLaren refers to himself as the "IP" (Independent Person) over 200 times in the document. The report is titled "The Independent

Table 2. Content Analysis Summary

\begin{tabular}{|c|c|c|c|c|c|c|c|c|c|c|c|c|}
\hline $\begin{array}{l}\text { Report } \\
\text { referred } \\
\text { to as: }\end{array}$ & Year & $\begin{array}{l}\text { Problem } \\
\text { type }\end{array}$ & Pages & Sport & $\begin{array}{l}\text { Is the organi- } \\
\text { zation funding } \\
\text { the investi- } \\
\text { gation the } \\
\text { subject of the } \\
\text { investigation? }\end{array}$ & \begin{tabular}{|l|} 
Known connec- \\
tion between \\
investigator/s \\
and report \\
commissioning \\
body (nature of \\
relationship)
\end{tabular} & $\begin{array}{l}\text { Review by } \\
\text { subject of } \\
\text { investigation } \\
\text { prior to } \\
\text { publication }\end{array}$ & $\begin{array}{l}\text { Scope: } \\
\text { punishment or } \\
\text { reform only }\end{array}$ & $\begin{array}{l}\text { Independent } \\
\text { word count } \\
\text { (in title: yes/ } \\
\text { no) }\end{array}$ & $\begin{array}{l}\text { Independent } \\
\text { rate per page }\end{array}$ & $\begin{array}{l}\text { Rationale for } \\
\text { independence } \\
\text { in report } \\
\text { (short } \\
\text { statement or } \\
\text { section) }\end{array}$ & $\begin{array}{l}\text { How } \\
\text { independence } \\
\text { claimed: }\end{array}$ \\
\hline Mitchell & 2007 & Doping & 409 & $\begin{array}{l}\text { Baseball } \\
\text { (MLB) }\end{array}$ & Yes & Yes (MLB team director) & Yes & Punishment & $\begin{array}{l}52 \\
\text { (yes) }\end{array}$ & .12 & Section & $\begin{array}{l}\text {-Externality. } \\
\text {-Disclose and dismiss potential conflicts } \\
\text { of interest. } \\
\text {-Claim no limits imposed on investigation } \\
\text { methodology. }\end{array}$ \\
\hline Pedowitz & 2008 & $\begin{array}{l}\text { Umpire } \\
\text { corruption/ } \\
\text { Gambling }\end{array}$ & 133 & $\begin{array}{l}\text { Basketball } \\
\text { (NBA) }\end{array}$ & Yes & No & Yes & Punishment & 1 & .007 & Statement & $\begin{array}{l}\text {-Claim no limits imposed on investigation } \\
\text { methodology. }\end{array}$ \\
\hline Gunn \& Rees & 2008 & Corruption & 66 & Tennis & Yes & No & Yes & Punishment & 5 & .07 & Minimal & -Externality. \\
\hline $\begin{array}{l}\text { Pieth FIFA } \\
\text { Report }\end{array}$ & 2011 & Governance & 39 & Soccer & Yes & No (future contract) & Yes & Reform Only & 19 & .48 & Statement & -Externality \\
\hline $\begin{array}{l}\text { FIFA IGC } \\
\text { Report I }\end{array}$ & 2012 & Governance & 20 & Soccer & Yes & Yes & Yes & Reform 0nly & 50 (yes) & 2.5 & Statement & $\begin{array}{l}\text {-Externality } \\
\text {-Thorough search procedure. }\end{array}$ \\
\hline USADA & 2013 & Doping & 202 & Cycling & No & $\begin{array}{l}\text { Yes (employed by } \\
\text { USADA) }\end{array}$ & No & Punishment & 11 & .05 & Statement & -Externality. \\
\hline Weiss & 2013 & Corruption & 469 & $\begin{array}{l}\text { Basketball } \\
\text { (NBPA) }\end{array}$ & Yes & No & $\begin{array}{l}\text { No (despite also fund- } \\
\text { ing investigation) }\end{array}$ & Punishment & 67 & .14 & Section & \begin{tabular}{|l}
-Externality. \\
- No document review prior to publication.
\end{tabular} \\
\hline $\begin{array}{l}\text { COCACAF } \\
\text { Integrity } \\
\text { Committee }\end{array}$ & 2013 & Corruption & 144 & Soccer & Yes & No & Yes & Punishment & 23 & .15 & Statement & -Externality. \\
\hline $\begin{array}{l}\text { FIFA IGC } \\
\text { Report II }\end{array}$ & 2013 & Governance & 10 & Soccer & Yes & Yes & Yes & Reform 0nly & 32 (yes) & 3.2 & Statement & $\begin{array}{l}\text {-Externality } \\
\text {-Thorough search procedure for committee } \\
\text { members. }\end{array}$ \\
\hline Wells I & 2014 & Bullying & 144 & NFL & Yes & $\begin{array}{l}\text { No (However future } \\
\text { services) }\end{array}$ & $\begin{array}{l}\text { Yes (by NFL, not } \\
\text { players) }\end{array}$ & Punishment & 16 & .11 & Statement & -Externality. \\
\hline
\end{tabular}


Person Report" (McLaren) but contained no rationale as to why the "IP" can be considered "independent." Yet, McLaren offered the following assurance:

The IP was appointed to lead this investigation to ensure an unbiased and independent examination of the evidence and from which all stakeholders could have confidence in the reporting of careful, thorough and balanced assessment of proven facts. The IP relied and built upon the work previously done by the IC (Independent Commission). (2016, p. 11)

Additionally, in the same report it is stated that McLaren "was previously a member of WADA's three-person Independent Commission ... which exposed widespread doping in Russian Athletics" (p. 3). Thus, the report emphasized that the "Independent Person" was previously associated with this issue. Overall, it is evident that the label of "independent" bears repeating, despite the absence of a clear or consistent definition.

\section{Conflicts of Interest and Arm's Length Investigation}

The second group of variables used in the analysis were related to conflicts of interest. In all except four of the reports (the exceptions were USADA, WADA IC I, WADA IC II, and McLaren IP), the entity responsible for the investigation was paid directly by the organization that was the subject of the investigation, or at least, the commissioning organization's reputation was tied to the outcome of the report. A related challenge to claims of independence was whether the funding organization reviewed the report prior to publication. The Weiss Report (2013) was the only one in the sample in which there was not a pre-publication review

Table 2. Content Analysis Summary (continued from page 109)

\begin{tabular}{|c|c|c|c|c|c|c|c|c|c|c|c|c|}
\hline $\begin{array}{l}\text { FIFA IGC } \\
\text { Report III }\end{array}$ & 2014 & Governance & 15 & Soccer & Yes & Yes & Yes & Reform Only & 59 (yes) & 3.9 & Statement & $\begin{array}{l}\text {-Externality } \\
\text {-Thorough search procedure for committee } \\
\text { members and exclusion of previous } \\
\text { members when }\end{array}$ \\
\hline Mueller & 2015 & \begin{tabular}{|l} 
Domestic \\
Violence
\end{tabular} & 96 & NFL & Yes & Yes (firm) & Yes & Punishment & $\begin{array}{l}17 \\
\text { (yes) }\end{array}$ & .177 & Section & $\begin{array}{l}\text {-Claim no limits imposed on investigation } \\
\text { methodology. } \\
\text {-Disclose and dismiss potential conflicts } \\
\text { of interest. }\end{array}$ \\
\hline Wells II & 2015 & Rule violation & 243 & NFL & Yes & Yes (firm) & $\begin{array}{l}\text { Yes (by NFL not } \\
\text { players) }\end{array}$ & Punishment & 8 & .03 & Section & $\begin{array}{l}\text {-Claim no limits imposed on investigation } \\
\text { methodology. }\end{array}$ \\
\hline CIRC Report & 2015 & Doping & 228 & Cycling & Yes & No & Yes & Punishment & $\begin{array}{l}53 \text { (yes) AND acronym } \\
\text { "CIRC" }>200 \text { times }\end{array}$ & $\begin{array}{l}.23 \\
(\mathrm{CIRC}>.87)\end{array}$ & Statement & $\begin{array}{l}\text {-Externality. } \\
\text {-Limited instruction and oversight of } \\
\text { investigation by UCl. }\end{array}$ \\
\hline WADA IC 1 & 2015 & $\begin{array}{l}\text { Doping and } \\
\text { Corruption }\end{array}$ & 335 & Athletics & No & Yes & $\begin{array}{l}\text { No (no review by } \\
\text { IAAF/ARAF) }\end{array}$ & Punishment & $\begin{array}{l}83 \text { (yes) AND } \\
\text { IC acronym }>700 \\
\text { times }\end{array}$ & $\begin{array}{l}.247 \\
(I C>2)\end{array}$ & Statement & -Externality \\
\hline McLaren IP & 2016 & Doping & 151 & \begin{tabular}{|l|} 
Olympic \\
(Summer, \\
Winter, Para) \\
\end{tabular} & No & $\begin{array}{l}\text { Yes } \\
\text { (previous associated } \\
\text { investigations) }\end{array}$ & No & Punishment & $\begin{array}{l}13 \text { (yes) AND "IP" } \\
\text { acronym used >200 } \\
\text { times }\end{array}$ & $\begin{array}{l}.086 \\
(I \mathbb{P}>1.32)\end{array}$ & Statement & -Externality. \\
\hline WADA IC II & 2016 & $\begin{array}{l}\text { Doping and } \\
\text { Corruption }\end{array}$ & 95 & Athletics & No & $\begin{array}{l}\text { Yes (previous associated } \\
\text { investigations) }\end{array}$ & $\begin{array}{l}\text { No (no review by } \\
\text { IAAF/ARAF) }\end{array}$ & Punishment & $\begin{array}{l}19 \text { (yes) AND } \\
\text { IC acronym } 130 \text { times }\end{array}$ & \begin{tabular}{|l}
.02 \\
$(I C 1.368)$
\end{tabular} & Statement & -Externality \\
\hline $\begin{array}{l}\text { Ruggie } \\
\text { Report }\end{array}$ & 2016 & \begin{tabular}{|l|} 
Corruption \\
and Human \\
Rights abuse
\end{tabular} & 42 & Soccer & Yes & No & Yes & Reform Only & 16 & .38 & Statement & \begin{tabular}{|l}
-Externality \\
-Final editorial right to investigator.
\end{tabular} \\
\hline
\end{tabular}


despite the subject of the investigation (National Basketball Players Assocation [NBPA]) also funding the investigation. In 11 of the reports there was a known connection between the investigator(s) and the entity funding the investigation. Therefore, in less than half of the reports there was no known existing relationship; however, in three of these cases subsequent services were provided to the funding organization by the investigator(s). The most obvious example in the sample was the fact that Wells performed the 2014 Miami Dolphins bullying investigation for the NFL (Wells I) and was commissioned again by the NFL in 2015 for the "Deflategate" Investigation (Wells II).

These conflict of interest issues gained some public attention, with media drawing attention to the Deflategate report (Wells II) and the millions of dollars received by Wells for writing the report (e.g., Florio, 2015; Hurley, 2015). Tom Brady received a four-game suspension from the NFL because of the investigation, and Brady's appeal of the suspension reached the federal courtroom. During the hearing, Judge Berman called into question the independence of Wells' report and in the decision, he wrote the word "independent" in quotation marks. One of the issues that Judge Berman highlighted was that the report was reviewed and revised by NFL in-house general counsel Jeff Pash prior to publication. Additionally, it was noted that Brady's lawyers had been denied the opportunity to question Pash during the arbitral hearing. Furthermore, Wells' law firm also served as the NFL's counsel in Brady's appeal hearing; specifically, Lorin Reisner, who was a co-author of the "independent" report, questioned Brady during the appeal proceedings. Judge Berman wrote:

\begin{abstract}
Denied the opportunity to examine Pash at the arbitral hearing, Brady was prejudiced. He was foreclosed from exploring, among other things, whether the Pash/Wells Investigation was truly "independent," and how and why the NFL's General Counsel came to edit a supposedly independent investigation report. "[The Report] was prepared entirely by the Paul, Weiss investigative team and presents the independent opinions of Mr. Wells and his colleagues." Brady was also prejudiced because there was no other witness, apart from Pash, who was as "competent to address the substantive core of the claim." As co-lead investigator and senior executive with the NFL, Pash was in the best position to testify about the NF's degree of involvement in, and potential shaping of, a heralded "independent" Investigation. (Nat'l Football League Mgmt. Council v. Nat'l Football League Players Ass'n, 2015)
\end{abstract}

In another example, the public perception of the Pieth FIFA Report was questioned when it was revealed that Pieth was paid $\$ 125,000$ and $\$ 5,000$ per day to complete the report, which was not disclosed (Pielke, 2011). Interestingly, in his initial report (Pieth FIFA Report), Pieth wrote about the necessity of conflict of interest policies at FIFA and advocated the disclosure of funds. In the FIFA IGC Report III, the reader is referred to the "new" FIFA's Governance Regulations for a definition of “independence." In FIFA's Governance Regulations (2014), the issue of monetary compensation is addressed whereby a requirement of "independence" is stated to be the absence of "material business relationships"-FIFA clarifies that "material business relationships" include "any confederation or

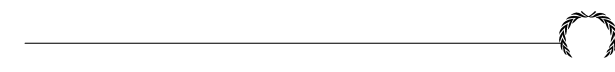


any member association for property or services in an amount which, in any single year, exceeds USD 125,000" (FIFA, 2014, p. 6). It is not surprising that this definition has been called in to question. For example, Roger Pielke Jr observed:

But perhaps the most revealing evidence that FIFA just doesn't "get it" is its newly proposed definition of what it means to be "independent" of FIFA. One can receive up to $\$ 125,000$ from FIFA, or related organizations, per year and still be considered "independent." ...The $\$ 125,000$ threshold for "independence" is likely a reflection of the incredible amounts of money sloshing around in international football. For many who participate in this world, $\$ 125,000$ probably is not a big deal ... But for most individuals who might be considered for independent roles with FIFA, $\$ 125,000$ is going to be of the same scale or larger than their primary salaries. (Pielke, 2015)

Interestingly, the CIRC Report did highlight processes that can limit "independence" when it related to other UCI operations. In the CIRC report, concerns regarding "independence" are mentioned in relation to the UCI's Ethics Commission, under the heading "Ethics Commission: independent or a façade?" (CIRC, 2015, p. 206). The CIRC Report highlighted that there were close ties between particular members of the Ethics Commission and UCI leadership. CIRC also raised concern over an instance whereby the President of the Ethics Commission sent draft rulings to the UCI leadership before formal decision. The report stated, "[s]uch a manner of operating is entirely contrary to due process and severely prejudicial to the independence and credibility of the Ethics Commission." (CIRC, 2015, p. 206). Yet, in a similar manner, CIRC was mandated to provide its own report to the UCI President and it was within the sole responsibility of UCI to publish the report. This process provides opportunity for selective publication, opportunistic editing, and raises questions of procedural transparency that may not be far removed from the aforementioned FIFA "summary" example.

\section{The Careful Selection of Scope}

The third set of variables concerned efforts made by the commissioning body to restrain the scope of the investigation. In all of the sample of reports, the commissioning body dictated the scope of the investigation. For each of the reports the Terms of Reference were examined and for every report the scope was pre-set at the time of hiring the investigator(s). Four of the reports claimed that the commissioning body did not impose limitations on investigation. Additionally, the five FIFA-related reports were restricted in scope in that these were only forward-looking and specifically restrained from looking in to past behaviors of the organization (reform only).

Despite the perception that these reports are the result of all-encompassing investigations, there is a limited scope (in substance and/or time) and jurisdiction. The investigations were each carried out by lawyers or experts, but these investigators did not have subpoena power and relied on voluntarily provided accounts and evidence. These investigations can only utilize the evidence made available to them. An illustrative example is in the Mitchell Report (2007), in which over 500 past and present players were asked to discuss steroid use in 
Major League Baseball and only 69 agreed to comment. The fact that the scope is pre-set at the time of hiring the investigator(s) restricts what these investigations can uncover. For example, what occurs if the investigators uncover something important beyond the confines of their pre-set scope? In the case of Wells I, the investigators were limited to investigate workplace conduct at the Miami Dolphins but only as related to bullying. When these investigators uncovered information relating to alleged drug use within the organization this was buried in a footnote as "beyond the scope of our mandate" (Wells et al., 2014, p. 26).

The Mueller Report was an example where the scope of the investigation was pre-established, yet it was claimed that the commissioning body did not impose limitations on the investigation. Mueller (2015) reported, "I had the sole discretion to employ investigative resources, techniques, and processes appropriate to complete the investigation and the report," (p. 10). The Mueller Report (2015) pertained to the Ray Rice domestic violence case; however, the scope of the investigation was limited. Specifically, the report stated:

This investigation does not address a number of issues. For example, we do not address the League's player discipline process generally or the specific discipline imposed on Rice by the League in July or September; the League's approach to domestic violence; or issues raised on appeal of Rice's discipline and decided by Judge Jones. (Mueller, 2015, p. 2)

Arguably, the issues excluded from the investigation were those of the greatest public concern and posed the greatest public relations threat for the NFL. This raised the question of the public relations function these reports may provide for the organization commissioning the investigation with the careful dictation of investigation scope providing an opportunity for selective findings.

An emergent theme that was recognized in the content analysis concerned that of the scope of the investigation. Many investigations did have the mandate of looking into past problems and resulted in punishments. However, in the five FIFA reports the emphasis was on future reform only (i.e., rather than elucidating past wrongdoings or blame that may evoke accountability, the focus is upon broader policy and governance structure moving forward). In a clear example of this trend:

(Pieth) was asked by FIFA to analyze the existing governance structure, to express an opinion on its standard and, if necessary, to make recommendations for its amendment. This is not an investigation into past behavior. The focus is exclusively on the institutional arrangements, the organizational structures and procedures and their ability to deal with existing risks and challenges. (Pieth, 2011, p. 7)

\section{Recommendations}

From the review and discussion of the 18 reports in the sample, recommendations for future investigative reports are provided and these guidelines can be utilized as criteria to evaluate future reports. First, the investigators should avoid an overstating of "independence" and any claims of "independence" should be 
clearly defined. Second, reports should include clear statements disclosing all known possible conflicts of interests with attention given to existing relationships between investigators and the organization. Certainly, the utilization of an inhouse co-investigator (e.g., Pash in Wells II) voids any claims of "independence." Third, there should be clear communication regarding funding provided for the investigation. Fourth, details of the selection process of the investigator should be readily available. Fifth, the scope of the investigation should not be unnecessarily confined and the investigator(s) should be afforded capacity to pursue alternative lines of inquiry their expertise deem important. Sixth, there should be minimal (if any) review of the document by the commissioning organization prior to publication, and the final publication approval rights must be given solely to the investigator(s).

\section{Conclusion}

The sample utilized in this study elucidates the efforts made by the report writers, and commissioning bodies, to emphasize and justify claims of "independence," yet the analysis highlighted readily identified markers that call into question these proclamations. This article provides a pilot study-level snapshot into issues surrounding the application of independent investigation reports in sport, and these issues are clearly pertinent to the global sports law community. Sport has become increasingly professionalized and the sport and business relationship has strengthened, increasing the complexity and number of ethical issues affecting modern sport management (Sherry et al., 2007). The scandals concerning FIFA have perpetuated the topic of sport governance into public discourse. However, the critique of sport governance has not previously been extended to the investigations linked to governance reform.

The sport scandal investigations could serve as an avenue for some accountability and for identifying necessary governance structure changes needed to bring sporting organizations in line with the magnitude of its operation. However, it is necessary to identify the limitations of these reports and to recognize that investigations cannot be accepted as "independent" from the context in which they arose. When sporting scandal occurs, the governance structures and integrity of the sporting code or body are brought into question-it is important to also ask to what extent these "independent" reports may be a symptom of, and perpetuating, the very issues that the investigations are intended to address. Optimistically, there is opportunity for such investigations to be a catalyst for genuine organization and policy reforms; however, the report alone is not reform. Thus, it is crucial that future studies assess whether there have been legitimate advancements after the publication of the relevant "independent" investigation documents.

\section{References}

Chien, P.M., Kelly, S.J., \& Weeks, C.S. (2016). Sport scandal and sponsorship decisions: Team identification matters. Journal of Sport Management, 30, 490-505. https://doi.org/10.1123/ jsm.2015-0327

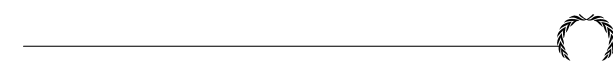


CONCACAF. (2013). Integrity committee report of investigation [online] Retrieved from https:// docs.google.com/viewer?a=v\&pid=sites\&srcid=d29ya2Vyc3VuaW9uLm9yZy50dHxuYXRpb25hbC13b3JrZXJzLXVuaW9ufGd4OjE4ZWVkMmZjNmI5NWY5MmU

FIFA. (2012). First report of the independent governance committee to the executive committee of FIFA. [online]. Retrieved from http://resources.fifa.com/mm/document/affederation/footballgovernance $/ 01 / 60 / 85 / 44 /$ first_report by_igc to fifa_exco $\% 5 \mathrm{~B} 2 \% 5 \mathrm{D}$.pdf

FIFA. (2013). Second report of the independent governance committee to the executive committee of FIFA. [online]. Retrieved from https://www.baselgovernance.org/sites/collective.localhost/ files/documents/igc/igc-report-2013.pdf

FIFA. (2014). Final report of the independent governance committee. [online]. Retrieved from http://www.fifa.com/governance/news/y=2014/m=4/news=final-report-of-the-independent-governance-committee-available-for-dow-2322854.html

FIFA. (2015). Governance regulations [online]. Retrieved from http://www.fifa.com/mm/document/affederation/administration/02/11/20/75/forenweb neutral.pdf

Fink, J. S., Parket, H. M., Brett, M., \& Higgins, J. (2009). Off-field behavior of athletes and team identification: Using social identity theory and balance theory to explain far reactions. Journal of Sport Management, 23, 142-155. https://doi.org/10.1123/jsm.23.2.142

Florio, M. (2015, August 6). Ted Wells “independent” investigator in name only. NBC Sports. [online]. Retrieved from http://profootballtalk.nbcsports.com/2015/08/06/ted-wells-independent-investigator-in-name-only/

Gunn, B., \& Rees, J. (2008). Environmental review of integrity in professional tennis. Retrieved from http://www.sportingintelligence.com/wp-content/uploads/2011/01/Integrity-in-tennis.pdf

Homewood, B. (2017, March 31). FIFA hands 1,300-page corruption report to Swiss authorities. Reuters. [online]. Retrieved from http://www.reuters.com/article/us-soccer-fifa-idUSKB$\underline{\text { N1721BD }}$ feedType $=$ RSS\&feedName $=$ sportsNews\&utm content=buffer32234\&utm medi$\underline{\mathrm{um}}=$ social\&utm_source=twitter.com\&utm_campaign $=$ buffer

Hsieh, H., \& Shannon, S. (2005). Three approaches to qualitative content analysis. Qualitative Health Research, 15, 1277-1288. https://doi.org/10.1177/1049732305276687

Hughes, S., \& Shank, M. (2005). Defining scandal in sports: Media and corporate sponsor perspectives. Sport Marketing Quarterly, 14, 207-216.

Hurley, M. (2015, May 12). Ted Wells claims impartiality despite multi-million dollar pay day from NFL. CBS Boston. [online]. Retrieved from http://boston.cbslocal.com/2015/05/12/hurleyted-wells-claims-impartiality-despite-multi-million-dollar-pay-day-from-nfl/

IAAF. (2016). Athletics integrity unit begins recruitment [online]. Retrieved from https://www. iaaf.org/news/press-release/athletics-integrity-unit-begins-recruitment

Independent. (2015, June 3). FIFA corruption timeline: the events that led to the resignation of Sepp Blatter. [online]. Retrieved from http://www.independent.co.uk/sport/football/international/fifa-corruption-timeline-the-events-that-led-up-to-the-resignation-of-president-sepp-blatter-10294646.html

Kassarjian, H. (1977). Content analysis in consumer research. Journal of Consumer Research, 4, 8-18. https://doi.org/10.1086/208674

Kuhn, T., \& Ashcraft, K. L. (2003). Corporate scandal and the theory of the firm. Management Communication Quarterly, 17, 20-57. https://doi.org/10.1177/0893318903253421

Lee, C., Bang. H., \& Lee, D. (2013). Regaining fans' trust after negative incidents: Fit between responses and nature of the incidents. Sport Marketing Quarterly, 22, 235-245. 
Levitt, A., \& Dwyer, P. (2002). Take on the street: What Wall Street and corporate America don't want you to know, and what you can do to fight back. New York, NY: Patheon.

Longman, J. (2014, December 17). FIFA investigator Michael J. Garcia quits in dispute over report. New York Times. Retrieved from http://www.nytimes.com/2014/12/18/sports/soccer/michael-j-garcia-resigns-as-fifa-prosecutor-in-protest.html? $\mathrm{r}=0$

McLaren, R. H. (2016). Independent Person Report Part II. Retrieved from https://www.wada-ama. org/en/resources/doping-control-process/mclaren-independent-investigation-report-part-ii

McLaren, R. H. (2011). Is sport losing its integrity? Marquette Sports Law Review, 21, 550-573.

Marty D., Nicholson P., \& Haas, U. (2015). Cycling Independent Reform Commission report to the president of the Union Cycliste Internationale. [online]. Retrieved from http://www.uci.ch/mm/ Document/News/CleanSport/16/87/99/CIRCReport2015 Neutral.pdf

Mitchell, G. J. (2007). Report to the Commissioner of baseball an independent investigation into the illegal use of steroids and other performance enhancing substances by players in Major League Baseball. [online]. Retrieved from http://files.mlb.com/mitchrpt.pdf

Moore, D. A., Tetlock, P. E., Tanlu, L., \& Bazerman, M. H. (2006). Conflicts of interest and the case of auditor independence: Moral seduction and strategic issue cycling. Academy of Management, 31, 10-29. https://doi.org/10.5465/amr.2006.19379621

Mueller, R. S. (2015). Report to the National Football League of an independent investigation into the Ray Rice incident. [online]. Retrieved from https://assets.documentcloud.org/documents/1392365/muellerfinalreport.pdf

Nat'l Football League Mgmt. Council v. Nat'l Football League Players Ass'n (Deflategate), Nos. 15 Civ. 5916 (RMB)(JCF), 15 Civ. 5982 (RMB) (JCF), 2015 WL 5148739 (S.D.N.Y. Sept. 3, 2015).

Paul, Weiss, Rifkind, Wharton, \& Garrison, LLP. (2013). Report to the special committee of the National Basketball Players Association concerning the leadership and business practices of the NBPA. [online]. Retrieved from http://www.nbpareport.com/

Patton, M. Q. (2002). Qualitative research and evaluation methods (3rd ed.). Thousand Oaks, CA: Sage.

Pedowitz, L. B. (2008). Report to the board of governors of the National Basketball Association. [online]. Retrieved from http://hosted.ap.org/specials/interactives/documents/100208nba_pedowitz.pdf

Pielke, R. (2011). Disclosure starts at home. [Web log post]. Retrieved from http://leastthing.blogspot.com.au/2011/12/disclosure-starts-at-home.html

Pielke, R. (2015, December 3). FIFA still doesn't get independence. [Web log post]. Retrieved from http://leastthing.blogspot.com.au/2015/12/fifa-still-doesnt-get-independence.html

Pieth, M. R. (2011). Governing FIFA. Retrieved from http://www.fifa.com/mm/document/affederation/footballgovernance/01/54/99/69/fifagutachten-en.pdf

Ruggie, J. G. (2016). FIFA and human rights. Retrieved from https://www.hks.harvard.edu/content/download/79736/1789834/version/1/file/Ruggie humanrightsFIFA reportApril2016.pdf

Sherry, E., Shilbury, D., \& Wood, G. (2007). Wrestling with "conflict of interest" in sport management. Corporate Governance, 7, 267-277. https://doi.org/10.1108/14720700710756544

USADA. (2013). Reasoned decision of the United States Anti-Doping Agency on disqualification and ineligibility. Retrieved from http://d3epuodzu3wuis.cloudfront.net/ReasonedDecision.pdf

WADA. (2015). Independent Commission report \#1. Retrieved from https://www.wada-ama.org/ en/resources/world-anti-doping-program/independent-commission-report-1

WADA. (2016). Independent Commission report \#2. Retrieved from https://www.wada-ama.org/ 
en/resources/world-anti-doping-program/independent-commission-report-2

Wells, T. V., Karp, B. S., Birenboim, B., \& Brown, D. W. (2014). Report to the National Football League concerning issues of workplace conduct at the Miami Dolphins. Retrieved from http:// workplacebullying.org/multi/pdf/PaulWeissReport.pdf

Wells, T. V., Karp, B. S., \& Reisnel, L. L. (2015). Investigative report concerning footballs used during the AFC championship game on January 18, 2015. Retrieved from https://nfllabor.files. wordpress.com/2015/05/investigative-and-expert-reports-re-footballs-used-during-afc-championsh.pdf

Wilson, B., Stavros, C., \& Westberg, K. (2008). Player transgressions and the management of the sport sponsor relationship. Public Relations Review, 34, 99-107. https://doi.org/10.1016/j. pubrev.2008.03.012 